\title{
Effect of Different Levels of Urea Super Granule and Prilled Urea on the Crop Quality, Nutrient Uptake and Soil Nutrient Status of Broccoli
}

\author{
M. J. Hussain ${ }^{1}$, A. J. M. S. Karim², A. R. M. Solaiman², M. S. Islam² and M. Rahman ${ }^{3}$ \\ ${ }^{1}$ Soil \& Water Management Section, Horticulture Research Centre, Bangladesh Agricultural Research \\ Institute, Gazipur, Bangladesh. ${ }^{2 \notin 3}$ Departments of Soil Science and Horticulture, Bangabandhu Sheikh \\ Mujibur Rahman Agricultural University, Gazipur, Bangladesh.
}

*Corresponding author and Email: hussainmdjamal@ymail.com

Received: 25 September 2017

Accepted: 22 December 2017

\begin{abstract}
A field experiment was conducted at Bangabandhu Sheikh Mujibur Rahman Agricultural University, Gazipur during the period 2010-2011 to assess the effect of urea super granule (USG) and prilled urea (PU) on the quality attributes (Compactness coefficient, Vitamin C, $\beta$-carotene and chlorophyll contents) of broccoli, to assess the comparative performance of USG and PU on nutrient uptake and uptake efficiency of broccoli plant, to assess the effect of different forms and levels of urea $\mathrm{N}$ on the post harvest soil nutrient status of broccoli field and to select the better doses of USG and PU for quality broccoli production in Shallow Red-Brown Terrace Soil under Madhupur Tract (AEZ-28). The experiment was laid out in a randomized complete block design with three replications having 17 treatments constituted with different levels of urea super granule (USG) and prilled urea (PU) as- $\mathrm{T}_{1}$ : N-control, $\mathrm{T}_{2}:$ PU-N ${ }_{80}, \mathrm{~T}_{3}:$ PU-N ${ }_{100}, \mathrm{~T}_{4}:$ PU-N $\mathrm{N}_{120}, \mathrm{~T}_{5}:$ PU-N $\mathrm{N}_{140}, \mathrm{~T}_{6}: \mathrm{PU}_{160}, \mathrm{~T}_{7}:$ PU-N ${ }_{180}, \mathrm{~T}_{8}:$ PU-N $\mathrm{N}_{200}$, $\mathrm{T}_{9}$ : PU-N $\mathrm{N}_{220}, \mathrm{~T}_{10}$ : USG-N $\mathrm{N}_{80}, \mathrm{~T}_{11}$ : USG-N $\mathrm{N}_{100}, \mathrm{~T}_{12}: \mathrm{USG}_{12} \mathrm{~N}_{120}, \mathrm{~T}_{13}$ : USG-N $\mathrm{N}_{140}, \mathrm{~T}_{14}$ : USG-N $\mathrm{N}_{160}, \mathrm{~T}_{15}$ : USG$\mathrm{N}_{180}, \mathrm{~T}_{16}$ : USG-N $\mathrm{N}_{200}, \mathrm{~T}_{17}$ and USG-N $\mathrm{N}_{220} \mathrm{~kg} \mathrm{ha}^{-1}$. Results revealed that the comparative performance of USG in relation to head quality (compactness coefficient, ascorbic acid, $\beta$-carotene and chlorophyll content), nutrient (NPKS) uptake and $\mathrm{N}$ uptake efficiency was found better as compared to PU. The compactness coefficient, $\beta$-carotene and chlorophyll contents were increased with increasing rate of $\mathrm{N}$ as well as USG and PU, but ascorbic acid content was slightly decreased with increasing rate of USG and PU. The maximum compactness coefficient (18.61) was found from the treatment USG- $\mathrm{N}_{180}$ that was followed by USG- $\mathrm{N}_{160}(18.24)$ and the highest $\beta$-carotene content $(0.401 \mathrm{mg} / 100 \mathrm{gFW})$ was found from USG- $\mathrm{N}_{160}$ followed by PU- $\mathrm{N}_{180}(0.40 \mathrm{mg} / 100 \mathrm{gFW})$. Similarly the highest chlorophyll-a content $(0.818 \mathrm{mg} / 100 \mathrm{gFW})$ was found from USG-N $\mathrm{N}_{180}$ followed by USG-N $\mathrm{N}_{160}(0.814 \mathrm{mg} / 100 \mathrm{gFW})$ and the highest chlorophyll-b content $(1.141 \mathrm{mg} / 100 \mathrm{~g} \mathrm{FW})$ was recorded from USG-N ${ }_{180}$. The higher nutrient uptake and $\mathrm{N}$ uptake efficiency $(108.531 \%)$ was obtained from USG treated plots over that of the PU. But $\mathrm{N}$ uptake efficiency was decreased with increasing rates of $\mathrm{N}$ fertilizer. But post harvest soil nitrogen status did not show any systematic trend although it was found higher in USG over PU. Similarly no remarkable changes were observed in post harvest soil P, K, S and B status for the crop. However, USG @ $160 \mathrm{~kg} \mathrm{~N} \mathrm{ha}^{-1}$ (USG-N ${ }_{160}$ ) followed by USG-N $\mathrm{N}_{140}$ and PU @ $180 \mathrm{~kg} \mathrm{~N} \mathrm{ha}^{-1}$ (PU$\mathrm{N}_{180}$ ) with other recommended doses of fertilizer could be suggested as USG and PU based fertilizer recommendation for a good quality broccoli production in terms of yield and quality in Silty Clay Loam Soil of Madhupur Tract.
\end{abstract}

Keywords: Broccoli, Urea super granule, Head quality, Nutrient uptake, Soil nutrient status. 


\section{Introduction}

Broccoli is the more nutritious vegetable and contains substantial quantities of protein, carbohydrates, $\mathrm{Ca}, \mathrm{P}, \mathrm{Fe}$, thiamine, riboflavin, and niacin with very high levels of carotene (vitamin A) and ascorbic acid (vitamin C) as reported by Kays (1914). Nutrient uptake and crop quality of broccoli is influenced by the application of different levels of N. Yoldas et al. (2008) reported that application of $\mathrm{N}$ increased $\mathrm{N}, \mathrm{P}, \mathrm{K}$ and $\mathrm{Fe}$ concentrations in broccoli head and the highest amount of the total $\mathrm{N}$ and $\mathrm{K}$ in broccoli heads was measured at $450 \mathrm{~kg} \mathrm{ha}^{-1} \mathrm{~N}$ application. Nitrogen management strategies should be adopted to minimize the different losses of nitrogen from soil to the environment as it is the most limiting factor for crop growth. However, excess application of nitrogen fertilizer may have a negative effect on the environment and human health (Neeteson and Carton 2001). The response to $\mathrm{N}$ depends on the availability of water, and on the supply of other nutrients. The apparent $\mathrm{N}$ recovery has been found to decrease with increasing fertilizer $\mathrm{N}$ application for several vegetable crops (Greenwood and Draycott, 1988). Bakker et al. (2009) reported that floret $\mathrm{NO}_{3}{ }^{-} \mathrm{N}$ concentration increased and vitamin $\mathrm{C}$ concentration decreased at high nitrogen rates. Averaarts and de Willigen (1999) found that band placement of $\mathrm{N}$ positively influenced $\mathrm{N}$ uptake. The increase of the $\mathrm{N}$ fertilizer dose induces increase of nitrate content in plant tissue of broccoli (Zebarth et al., 1995). Fatemeh and Ahmad (2012) reported that the $\mathrm{N}, \mathrm{P}, \mathrm{K}, \mathrm{Fe}$, and $\mathrm{Zn}$ concentrations in broccoli head were positively affected by $\mathrm{N}$ treatments and the maximum $\mathrm{N}$ concentration $(7.18 \%)$ in the heads was determined at $400 \mathrm{~kg} \mathrm{~N}$ ha $^{-1}$ applied and $\mathrm{K}, \mathrm{P}$ and $\mathrm{Fe}$ concentrations $\left(0.78 \%, 2.41 \%\right.$ and $177.0 \mathrm{mg} \mathrm{kg}^{-1}$, respectively) were reached maximum at $300 \mathrm{~kg} \mathrm{~N} \mathrm{ha}^{-1}$ dose. Utilization of fertilizer $\mathrm{P}$ is generally enhanced by the application of $\mathrm{N}$ (William, 1958).

Murcia et al. (2000) studied chlorophylls $a$ and $b$ quantitatively determined in raw, frozen and canned florets and stems of broccoli and reported that the chlorophyll $a$ and $b$ contents were 0.11 and $0.043 \mathrm{~g} \mathrm{~kg}^{-1}$ fresh weight respectively in raw florets and 0.036 and $0.018 \mathrm{~g} \mathrm{~kg}^{-1}$, respectively in stems that was influenced by the $\mathrm{N}$ application. Nitrogen nutrition has a significant impact not only on the amount of harvested broccoli, but also on the content of $\beta$-carotene, vitamin $C$ and $E_{1}$. Lisiewska and Kmiecik (1996) determined that an increase in nitrogen rates from 80 to $120 \mathrm{~kg} \mathrm{ha}^{-1}$ results in a 44 and $33 \%$ reduction in vitamin $\mathrm{C}$ levels in broccoli and cauliflower, respectively. The concentration of $\beta$-carotene increases with increasing nitrogen rates. Ljiljana et al. (2012) reported that the increase in nitrogen fertilizer rate from 60 to 120 $\mathrm{kg} \mathrm{N} \mathrm{ha}^{-1}$ led to a reduction in vitamin $\mathrm{C}$ content and an increase in B-carotene. Hocmuth et al. (1999) used nitrogen rates of 0 to $220 \mathrm{~kg} \mathrm{ha}^{-1}$ and obtained the highest content of B-carotene (55 $\mathrm{mg} \mathrm{kg}^{-1}$ ) with $160 \mathrm{~kg} \mathrm{ha}^{-1}$. Similarly, the effect of different forms and levels of urea $\mathrm{N}$ on the post harvest soil status of broccoli field was observed by different scientists. Averaarts and de Willigen (1999) reported that the amount of mineral $\mathrm{N}$ in the soil at harvest generally increased with increasing amounts of $\mathrm{N}$ applied. So, the assessment of crop quality and plant nutrient uptake as well as post harvest soil nutrient status as affected by the $\mathrm{N}$ levels is important for quality broccoli production. Therefore, the experiment was undertaken (i) to assess the effect of urea super granule (USG) and prilled urea (PU) on the quality attributes (Compactness coefficient, Vitamin C, $\beta$-carotene and chlorophyll contents) of broccoli; (ii) to assess the comparative performance of USG and PU on nutrient uptake and uptake efficiency of broccoli plant; (iii) to assess the effect of different forms and levels of urea $\mathrm{N}$ on the post harvest soil nutrient status of broccoli field and (iv) to select the better doses of USG and PU for quality broccoli production.

\section{Materials and Methods}

A field experiment was conducted at Bangabandhu Sheikh Mujibur Rahman Agricultural University, Gazipur during the 
period 2010-2011 in Shallow Red-Brown Terrace Soil under Madhupur Tract (AEZ-28). The experiment was laid out in a randomized complete block design with three replications having 17 treatment combinations constituted with different levels USG and PU as- $\mathrm{T}_{1}$ : Ncontrol, $\mathrm{T}_{2}$ : PU-N $\mathrm{N}_{80}\left(80 \mathrm{~kg} \mathrm{~N}\right.$ as PU), $\mathrm{T}_{3}$ : PU$\mathrm{N}_{100}(100 \mathrm{~kg} \mathrm{~N}$ as $\mathrm{PU}), \mathrm{T}_{4}$ : PU-N $120(120 \mathrm{~kg} \mathrm{~N}$ as $\mathrm{PU}), \mathrm{T}_{5}: \mathrm{PU}-\mathrm{N}_{140}\left(140 \mathrm{~kg} \mathrm{~N}\right.$ as PU), $\mathrm{T}_{6}: \mathrm{PU}_{-\mathrm{N}_{160}}$ (160 kg N as PU), $\mathrm{T}_{7}$ : PU-N ${ }_{180}(180 \mathrm{~kg} \mathrm{~N}$ as PU), $\mathrm{T}_{8}$ : PU-N 200 (200 kg N PU), $\mathrm{T}_{9}$ : PU-N $220(220 \mathrm{~kg}$ $\mathrm{N}$ as PU), $\mathrm{T}_{10}$ : USG-N $\mathrm{N}_{80}$ (80 $\mathrm{kg} \mathrm{N}$ as USG), $\mathrm{T}_{11}$ : USG-N $_{100}\left(100 \mathrm{~kg} \mathrm{~N}\right.$ as USG), $\mathrm{T}_{12}$ : USG-N 120 (120 kg N as USG), $\mathrm{T}_{13}$ : USG-N $\mathrm{N}_{140}(140 \mathrm{~kg} \mathrm{~N}$ as USG), $\mathrm{T}_{14}$ : USG- $\mathrm{N}_{160}$ (160 kg N as USG), $\mathrm{T}_{15}$ : USG-N $_{180}$ (180 kg N as USG), T 16 : USG-N 200 (200 kg N as USG), $\mathrm{T}_{17}$ : USG-N $220(220 \mathrm{~kg} \mathrm{~N}$ as USG).

Soil sample of the experimental plot was collected prior to initiation of the experiment and analysis was done accordingly. For each plot 5 samples of $0-15 \mathrm{~cm}$ depth were randomly collected, mixed well, air-dried, ground and sieved through a $2 \mathrm{~mm}$ (10 mesh) sieve. The soil of the experimental field belongs to Salna series representing the Shallow Red Brown Terrace soil in Bangladesh soil classification system, which falls under order Inceptisols in Soil Taxonomy (Brammer, 1980 and FAO, 1988). But the soil of the study area is silty clay loam in texture with sand, silt and clay 17.8, 45.6 and $36.6 \%$, respectively and having bulk density $1.34 \mathrm{~g} / \mathrm{cc}$ and particle density $2.61 \mathrm{~g} / \mathrm{cc}$, porosity $47.47 \%$ and field capacity $28.67 \%$. The initial soil sample of $0-15 \mathrm{~cm}$ depth was collected from the experimental unit plots before fertilization. Postharvest soil samples of 0-15 cm depth were also collected from each plot and the samples were stored in clean plastic bag for physical and chemical analyses. At the same time, undisturbed soil samples from $0-15 \mathrm{~cm}$ were collected for determination of soil bulk density. The initial soil sample was analyzed for particle size distribution, particle density, bulk density, $\mathrm{pH}$, organic $\mathrm{C}$, total $\mathrm{N}$, available $\mathrm{P}$, exchangeable $\mathrm{K}$ and available $\mathrm{S}$ and $\mathrm{B}$. Chemical analysis of soil was done in the BSMRAU laboratory of the Department of Soil Science and the results obtained were presented in Table 1.

Post harvest soil samples were also analyzed for total $\mathrm{N}$, available $\mathrm{P}$, exchangeable $\mathrm{K}$, available $\mathrm{S}$ and $\mathrm{B}$. Soil $\mathrm{pH}$ was measured with the help of a glass electrode $\mathrm{pH}$ meter using soil water suspension of 1: 2.5 as described by Jackson (1962). Organic carbon was determined following the wet oxidation method as described by Page et al. (1982) and the organic matter content was calculated by multiplying the \% organic carbon with the Van Bemmelen factor 1.73 (Piper, 1950). Cation exchange capacity (CEC) was determined followed by ammonium acetate extraction method using flamephotometer. Total $\mathrm{N}$ of soil was estimated following the micro-Kjeldahl method (Jackson et al., 1973).

Table 1. Chemical properties of the initial soil of the experimental plot

\begin{tabular}{lc}
\hline Soil properties $(0-15 \mathrm{~cm}$ soil depth) & Analytical value \\
\hline Soil $\mathrm{pH}$ & 5.98 \\
Organic carbon $(\%)$ & 0.97 \\
Total N $(\%)$ & 0.11 \\
Available P $(\mu \mathrm{g}$ g-1) & 14.17 \\
Exchangeable K (meq/100g soil) & 0.32 \\
Available S $(\mu \mathrm{g}$ g-1) & 13.81 \\
Available B $(\mu \mathrm{g}$ g- 1$)$ & 0.20 \\
CEC $($ meq/100g soil) & 12.71 \\
\hline
\end{tabular}


The $\mathrm{P}$ was determined colorimetrically through extraction method (Olsen et al., 1954). Exchangeable $\mathrm{K}$ of soil was determined from ammonium acetate $\left(1 \mathrm{~N} \mathrm{NH}_{4} \mathrm{OAC}\right)$ extract as described by Jackson (1973). Available S in soil was determined by extracting the samples with $\mathrm{CaCl}_{2}(0.15 \%)$ solution using double beam spectrophotometer at $420 \mathrm{~nm}$ wave length followed by tubidimetrically with barium sulfate (Page et al., 1982). Total B content was determined followed by digestion with concentrated $\mathrm{HNO}_{3}$ and $\mathrm{HClO}_{4}$ (Par-chloric acid) method (Hunter, 1980) using double beam spectrophotometer (Model no. 200-20, Hitachi, Japan).

Compactness coefficient (CC) is the ratio of head yield $\left(\mathrm{g} \mathrm{plant}^{-1}\right)$ to head diameter $(\mathrm{cm})$. It was estimated by the following formula:

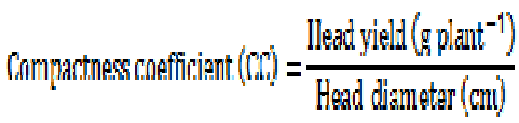

Ascorbic acid level was determined by the Iodate method of Samotus et al. (1982). Ascorbic acid (Vitamin C) content of fresh head sample was determined using centrifuging technique and $\mathrm{KIO}_{3}$ titration method followed by the formula stated below:

Ascorbic acid $(\mathrm{ng} / 100 \mathrm{gFW})=\frac{\left.\text { if } \times 7_{1} \times V_{2} \times 100\right)}{\left(\mathrm{W} \times V_{3}\right)} \quad \mathrm{Fq} .2$

Where,

$\mathrm{V}_{2}=$ Total volume of blended sample $(100 \mathrm{ml})$

$\mathrm{V}_{3}=$ Volume of sample extract taken $(5 \mathrm{ml})$

$\mathrm{W}=$ Weight of fresh head sample $(20 \mathrm{~g})$

$\mathrm{V}_{1}=$ Titrated volume of $\mathrm{KIO}_{3}(\mathrm{ml})$

Chlorophyll a, Chlorophyll b and Beta-carotene were determined followed by acetone-haxen method as stated by Masayasu and Yamashita (1992). This is a simple method for simultaneous determination of pigment in the vegetable. All pigments in sample are extracted with acetonehexane (4:6) at once. Then optical density of the supernatant at $663 \mathrm{~nm}, 645 \mathrm{~nm}, 505 \mathrm{~nm}$ and 453 $\mathrm{nm}$ are measured by spectrophotometer at the same time. From these values, the contents of
Chlorophyll a, Chlorophyll b and Beta-carotene could be estimated using the proposed formula as follows:

Chlorophyll a $(\mathrm{mg} / 100 \mathrm{ml})=0.999 \mathrm{~A}_{663}-0.0989 \mathrm{~A}_{645} \quad \mathrm{Eq} 3$

Chlcrophyll b (mg/100 ml) $=0.328 \mathrm{~A}_{663}+1.77 \mathrm{~A}_{645} \quad \mathrm{Eq} .4$

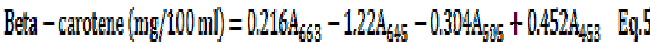
* $\mathrm{A}_{663}, \mathrm{~A}_{645}, \mathrm{~A}_{505}, \mathrm{~A}_{453}$ are absorbance at $663 \mathrm{~nm}$, $645 \mathrm{~nm}, 505 \mathrm{~nm}$ and $453 \mathrm{~nm}$, respectively.

Total plant biomass was estimated by oven drying the plant samples at $65^{\circ}-70^{\circ} \mathrm{C}$ for 72 hours and weighing. The biomass per plant and biomass per hectare were calculated by the following formulae:

Binmags per plant $(\mathrm{g})=\frac{\text { Total above ground biologicalyiald of } 10 \text { plants }(g)}{10}$ Figh

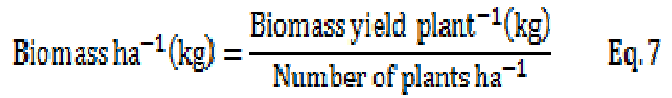

To evaluate the leaf nutrient content leaf samples were collected from three matured leaf of five randomly selected plants from each treatment, which were then oven dried and ground for analysis, at harvesting stage. To estimate the quality of head five randomly selected plants were taken into account from each treatment and head samples were collected from the head of these plants. The collected head samples were divided into two parts and one part is used for immediate analysis of vitamin-C, $\beta$-carotene and chlorophyll content. The other part was taken to air and oven dry for nutrient analysis. Leaf, stem and head samples of broccoli were dried in an oven at $65-70^{\circ} \mathrm{C}$ for 72 hours and then ground by a grinding machine to pass through a 20 mesh sieve and stored in small paper bags and kept into a desiccator. Representative plant samples were also dried and prepared for analysis. The samples were analyzed for $\mathrm{N}, \mathrm{P}, \mathrm{K}$ and $\mathrm{S}$ contents.

Nitrogen contents in the leaf stem and head sample were determined following the MicroKjeldahl method as described in case of soil 
analyses. Phosphorus concentration in the leaf, stem and head samples were determined after digestion with $\mathrm{HNO}_{3}$ and $\mathrm{HClO}_{4}$ mixture in 5:2 ratios. Phosphorus was determined from the digest by adding ammonium molybdate and ammonium vanadate solution and measuring the colour with the help of a double beam spectrophotometer (Model no. 200-20, Hitachi, Japan) at $660 \mathrm{~nm}$ wave lengths. Potassium content in leaf, stem and head samples were determined directly with the help of flame photometer after digesting the samples with diacid mixture. Sulphur content in the digest was determined by adding $6 \mathrm{~N} \mathrm{HCl}$ to plant extract and then precipitating with $\mathrm{BaCl}_{2}$ and measuring the turbidity calorimetrically at $420 \mathrm{~nm}$ wavelength (Black, 1965).

\section{Nutrient uptake assessment}

Nutrient uptake from the soil was calculated by using the formula:

Nutrient uptake $\left(\mathrm{kg} \mathrm{ha}^{-1}\right)=\frac{\% \text { Nutrlent } \mathrm{x} Y\left(\mathrm{~kg} \mathrm{ha}^{-1}\right)}{100} \quad$ Eq.8

Here,

$\%$ Nutrient $=$ Average nutrient content $(\%)$ of plant or head biomass

$\mathrm{Y}\left(\mathrm{kgha}^{-1}\right)=$ Total dry matter production of plant or head biomass

Nutriant uptake $\left(\mathrm{kg} \mathrm{ha}^{-1}\right)=\frac{\text { Nutrert }(\mu \mathrm{g} / \mathrm{g}) \times \mathrm{Y}\left(\mathrm{kg} \mathrm{ha}^{-1}\right)}{10^{6}}$

Here,

Nutrient $\left(\mu \mathrm{g} \mathrm{g}^{-1}\right)=$ Average nutrient content $(\mu \mathrm{g}$ $\left.\mathrm{g}^{-1}\right)$ of plant or head biomass

$\mathrm{Y}\left(\mathrm{kg} \mathrm{ha}^{-1}\right)=$ Total dry matter production of plant or head biomass

\section{Nitrogen uptake efficiency}

Nitrogen uptake efficiency (NUE) was determined by the ratio of $\mathrm{N}$ in the crop at harvest compared to $\mathrm{N}$ applied by subtracting the uptake made by the control plot. The efficiency of applied fertilizer $\mathrm{N}$ may be quantified by the following equation as stated by Craswell and Godwin (1984):

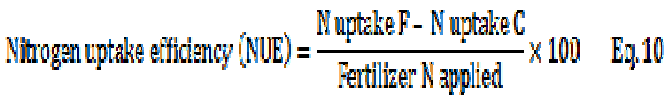

Where,

$\mathrm{F}$ and $\mathrm{C}$ denote fertilized crop and unfertilized control, respectively.

The collected data were compiled and tabulated in proper form and statistical analysis was done by using the computer package MSTATC. Computation and preparation of graphs were made by the use of Microsoft Excel 2003 program.

\section{Results and Discussion}

\subsection{Effects on the quality attributes of broccoli} 3.1.1. Compactness coefficient

A significant effect of different forms and levels of urea on the head compactness coefficient (CC) was found (Table 2). The maximum CC (18.61) was found from the treatment . USG-N $\mathrm{N}_{180}$ followed by USG-N $\mathrm{N}_{160}$ (18.24) which was significantly $(\mathrm{P} \leq 0.05)$ higher than all other treatments (Table 2). The lowest CC (12.56) was found from control where no urea was applied. In each level of $\mathrm{N}$ application $\mathrm{CC}$ was always higher in USG treated crop. Renata et al. (2005) reported that the $\mathrm{CC}$ was increased with increasing levels of $\mathrm{N}$, which is in agreement with the present findings. The probable reasons for higher compactness coefficient is might be due to the sufficient supply of plants in nitrogen, leading to sufficient carbon assimilation, resulting in translocation of current photosynthates to the broccoli head which in turns improve head compactness.

\subsubsection{Vitamin -C content}

The different form and levels of urea $\mathrm{N}$ significantly influenced vitamin-C or ascorbic acid content of the broccoli floret and vitamin-C content was gradually decreased with increasing rate of USG and PU (Table 2). The highest vitamin-C content (94.73 mg $100 \mathrm{~g}^{-1} \mathrm{FW}$ ) was recorded from the treatment USG- $\mathrm{N}_{80}$ followed

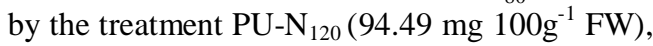
which were statistically identical with the treatment USG-N $\mathrm{N}_{100}$. However, Vitamin-C 
content in USG treated broccoli was found higher at each dose of $\mathrm{N}$ application. The lowest ascorbic acid content $\left(55.71 \mathrm{mg} 100 \mathrm{~g}^{-1} \mathrm{FW}\right)$ was found from $220 \mathrm{~kg}$ PU which was statistically identical with PU-N ${ }_{100}$ treatment. Chao-Jiong et al. (2010) reported that the ascorbic acid and glucoraphanine concentrations in broccoli floret and stem were decreased with the increase in higher $\mathrm{N}$ application, and significant lower levels of ascorbic acid were detected by $\mathrm{N}$ fertilization at range of $\mathrm{N} 300-400 \mathrm{~kg} \mathrm{ha}^{-1}$. Lisiewska and Kmiecik (1996) determined that an increase in nitrogen rates from 80 to $120 \mathrm{~kg} \mathrm{ha}^{-1}$ results in a 44 and $33 \%$ reduction in vitamin C levels in broccoli and cauliflower, respectively. Ljiljana et al. (2012) found that the increase in nitrogen fertilizer rate from 60 to $120 \mathrm{~kg} \mathrm{~N} \mathrm{ha}^{-1}$ led to a reduction in vitamin $\mathrm{C}$ content and an increase in B-carotene in carrot. Karitonas (2001) studied with $\mathrm{N}$ supply (60 to $300 \mathrm{~kg} \mathrm{ha}^{-1}$ ) on the yield and quality of broccoli and found that an increased level of $\mathrm{N}$ supply slightly reduced the vitamin $\mathrm{C}$ content from 83 to $73 \mathrm{mg} / 100 \mathrm{~g} \mathrm{f.m}$. in broccoli flowers which also correlated our finding at higher $\mathrm{N}$ levels. This was might be due to the higher nitrogen doses which reduced dry matter content resulting in less ascorbic acid in broccoli (Roni et al., 2014).

\subsubsection{Beta-carotene content}

The different forms and levels of urea $\mathrm{N}$ significantly influenced $\beta$-carotene content of broccoli floret (Table 2 ). The highest $\beta$-carotene

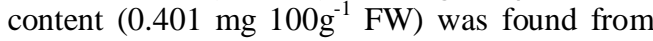
the treatment USG-N $\mathrm{N}_{160}$ that was statistically identical with the treatments $\mathrm{PU}-\mathrm{N}_{180}(0.40$ $\mathrm{mg} / 100 \mathrm{gFW})$, PU-N 160 , PU-N $140, \mathrm{USG} \mathrm{N}_{180}$ and USG-N $\mathrm{N}_{140}$. The significantly lowest $\beta$-carotene was recorded from PU-N $80\left(0.187 \mathrm{mg}^{\left.100 \mathrm{~g}^{-1} \mathrm{FW}\right)}\right.$ treatment.

Table 2. Effect different forms and levels of urea $\mathrm{N}$ on head quality of broccoli

\begin{tabular}{|c|c|c|c|c|c|}
\hline Treatments & $\begin{array}{l}\text { Compactness } \\
\text { coefficient } \\
\text { (cc) }\end{array}$ & $\begin{array}{l}\text { Vitamin-C } \\
(\mathrm{mg} / 100 \mathrm{~g} \mathrm{FW})\end{array}$ & $\begin{array}{l}\text { B-carotene } \\
(\mathrm{mg} / 100 \mathrm{~g} \mathrm{FW})\end{array}$ & $\begin{array}{l}\text { Chlophyll-a } \\
\text { (mg/100g FW) }\end{array}$ & $\begin{array}{l}\text { Chlophyll-b } \\
\text { (mg/100g } \\
\text { FW) }\end{array}$ \\
\hline $\mathrm{N}$-control & $12.93 \mathrm{hi}$ & $87.35 \mathrm{c}$ & 0.249 c-e & 0.648 & $0.751 \mathrm{~m}$ \\
\hline PU-N 80 & $14.15 \mathrm{gh}$ & $94.49 \mathrm{a}$ & $0.187 \mathrm{e}$ & 0.693 & $0.803 \mathrm{k}$ \\
\hline PU-N 100 & $14.08 \mathrm{gh}$ & $82.00 \mathrm{~d}$ & $0.222 \mathrm{de}$ & 0.712 & $0.839 \mathrm{j}$ \\
\hline PU-N 120 & $14.71 \mathrm{fg}$ & $77.68 \mathrm{e}$ & $0.220 \mathrm{de}$ & 0.755 & $1.037 \mathrm{ef}$ \\
\hline PU-N 140 & $15.85 \mathrm{~d}-\mathrm{f}$ & $70.92 \mathrm{f}$ & $0.321 \mathrm{a}-\mathrm{c}$ & 0.771 & $1.039 \mathrm{e}$ \\
\hline PU-N 160 & 15.55 ef & $68.16 \mathrm{fg}$ & $0.379 \mathrm{a}$ & 0.779 & $1.101 \mathrm{c}$ \\
\hline PU-N 180 & $16.41 \quad \mathrm{c}-\mathrm{e}$ & 64.44 hi & $0.400 \mathrm{a}$ & 0.795 & $1.114 \mathrm{bc}$ \\
\hline PU-N ${ }_{200}$ & $14.77 \mathrm{fg}$ & $56.72 \mathrm{j}$ & $0.286 \mathrm{~b}-\mathrm{d}$ & 0.799 & $1.076 \mathrm{~d}$ \\
\hline PU-N 220 & $15.20 \mathrm{e}-\mathrm{g}$ & $55.71 \mathrm{j}$ & $0.219 \mathrm{de}$ & 0.792 & $1.040 \mathrm{e}$ \\
\hline USG-N $_{80}$ & $15.76 \mathrm{~d}-\mathrm{f}$ & $94.73 \mathrm{a}$ & $0.214 \mathrm{de}$ & 0.767 & $0.812 \mathrm{k}$ \\
\hline USG-N$_{100}$ & $16.29 \mathrm{c}-\mathrm{e}$ & $93.65 \mathrm{ab}$ & 0.254 c-e & 0.773 & $0.859 \mathrm{i}$ \\
\hline $\mathrm{USG} \mathrm{N}_{120}$ & $16.98 \mathrm{bc}$ & $91.07 \mathrm{~b}$ & $0.289 \mathrm{~b}-\mathrm{d}$ & 0.788 & $0.970 \mathrm{~h}$ \\
\hline $\mathrm{USG} \mathrm{N}_{140}$ & $17.33 \mathrm{~b}-\mathrm{d}$ & $79.32 \mathrm{de}$ & $0.354 \mathrm{ab}$ & 0.797 & $1.042 \mathrm{e}$ \\
\hline USG-N$_{160}$ & $18.24 \mathrm{a}$ & $70.02 \mathrm{fg}$ & $0.401 \mathrm{a}$ & 0.814 & $1.122 \mathrm{~b}$ \\
\hline USG-N $_{180}$ & $18.61 \mathrm{a}$ & $68.40 \mathrm{fg}$ & $0.346 \mathrm{ab}$ & 0.818 & $1.141 \mathrm{a}$ \\
\hline USG-N$_{200}$ & $17.73 \mathrm{~b}$ & $67.12 \mathrm{gh}$ & $0.279 \mathrm{~b}-\mathrm{d}$ & 0.807 & $1.021 \mathrm{fg}$ \\
\hline USG-N$_{220}$ & $16.35 \mathrm{c}-\mathrm{e}$ & $63.12 \mathrm{i}$ & $0.275 \mathrm{~b}-\mathrm{d}$ & 0.803 & $1.007 \mathrm{~g}$ \\
\hline $\mathrm{CV}(\%)$ & 4.20 & 2.42 & 14.45 & 5.79 & 2.15 \\
\hline $\mathrm{SE}( \pm 0.05)$ & 0.3674 & 1.054 & 0.026 & ns & 0.006 \\
\hline
\end{tabular}

Means followed by uncommon letters are statistically different from each other at $5 \%$ level of probability by DMRT 
Here, it was also observed that comparatively higher $\beta$-carotene was contained by the USG treated plots than that of PU. These higher nutritional values obtained by applying USG due to its continuous and balanced $\mathrm{N}$ supply to the broccoli head. Anton et al. (2014) reported that nitrogen nutrition has a positive effect on increasing the amount of $\beta$-carotene in broccoli rosettes. Ljiljana et al. (2012) reported that $\beta$ carotene content increased with increasing rates of nitrogen and was found to be statistically significant even at 120 and $180 \mathrm{~kg} \mathrm{~N} \mathrm{ha}^{-1}$, as compared to both the control and $60 \mathrm{~kg} \mathrm{~N} \mathrm{ha}^{-1}$. Hocmuth et al. (1999) also obtained the highest content of $\beta$-carotene $\left(55 \mathrm{mg} \mathrm{kg}^{-1}\right)$ with $160 \mathrm{~kg} \mathrm{~N}$ $\mathrm{ha}^{-1}$ using $\mathrm{N}$ rates of 0 to $220 \mathrm{~kg} \mathrm{ha}^{-1}$.

\subsubsection{Chlorophyll-a content}

Chlorophyll-a content was increased with increasing levels of nitrogenous fertilizer (Table 2). Although there was no significant effect was found among the treatment highest chlorophyll-a $\left(0.818 \mathrm{mg} 100 \mathrm{~g}^{-1} \mathrm{FW}\right)$ content was found from USG-N $_{180}$ followed by USG-N ${ }_{160}(0.814 \mathrm{mg}$ $\left.100 \mathrm{~g}^{-1} \mathrm{FW}\right)$. However, the higher chlorophyll-a content was resulted in USG treated plots than that of PU. These results are supported by the findings of Karitonas (2001) who reported from their study by investigating the effect of varying $\mathrm{N}$ supply (60 to $300 \mathrm{~kg} \mathrm{ha}^{-1}$ ) on the yield and quality of broccoli and found the increased $\mathrm{N}$ supply improved chlorophyll contents in florets. Ouda and Mahadeen (2008) reported that chlorophyll content and head diameter were higher when a combination of organic and inorganic fertilizers was added compared to their individual addition. .

\subsubsection{Chlorophyll-b content}

In case of Chlorophyll-b content, a significant difference was observed among the treatments (Table 2). It was observed that chlorophyll-b content was increased with increasing levels of nitrogenous fertilizer. The highest chlorophyll-b content (1.141 mg $\left.100 \mathrm{~g}^{-1} \mathrm{FW}\right)$ was recorded from the treatment USG- $\mathrm{N}_{180}$, which was statistically different from all other treatments. The second highest chlorophyll-b content (1.122 mg $100 \mathrm{~g}^{-1} \mathrm{FW}$ ) was recorded from USG-N 160 followed by PU-N 180 (1.114 mg $\left.100 \mathrm{~g}^{-1} \mathrm{FW}\right)$ which was statistically identical with each other. The lowest chlorophyll-b content $(0.751 \mathrm{mg}$ $100 \mathrm{~g}^{-1} \mathrm{FW}$ ) was obtained from control. It was clearly observed that the higher chlorophyll-b content was found from USG treated plots than that of PU. This result is corroborated with the findings of Karitonas (2001) and Ouda and Mahadeen (2008), who reported that the increased $\mathrm{N}$ supply improved florets chlorophyll contents. This is due to a promotion effect of $\mathrm{N}$ fertilizer on chlorophyll formation might be attributed to the fact that $\mathrm{N}$ is a constituent of chlorophyll molecule. Moreover, nitrogen is the main constituent of all amino acids in proteins and lipids that acting as a structural compounds of the chloroplast (Arisha and Bradisi, 1999).

\subsection{Effects on plant nutrient uptake of broccoli 3.2.1. Nitrogen uptake by the crop}

The effect of different forms and levels of urea nitrogen on the $\mathrm{N}$ uptake and its uptake efficiency is presented in the Fig.1. Nitrogen uptake was increased significantly with increasing levels of $\mathrm{N}$ which followed a curvilinear fashion and the highest $\mathrm{N}$ uptake (280.2 $\mathrm{kg} \mathrm{ha}^{-1}$ ) was recorded from USG-N 180 treatment which was statistically identical with USG-N $\mathrm{N}_{200}$ and USG-N $\mathrm{N}_{160}$ treatments. The highest $\mathrm{N}\left(240.9 \mathrm{~kg} \mathrm{ha}^{-1}\right)$ uptake from PU treated plots was recorded from the treatment $\mathrm{PU}-\mathrm{N}_{180}$. The overall $\mathrm{N}$ uptake performance was higher in USG treated plots than that of PU. This might be due to higher and continuous availability of $\mathrm{N}$ and better growth of the crop, higher dry matter weight, $\mathrm{N}$ content and minimum volatilization loss of $\mathrm{N}$ due to deep placement of USG that have lead to higher $\mathrm{N}$ harvest and greater fertilizer-N recovery than that of PU (Khalil et al., 2006). The possible reason for higher uptake is that as USG placed at deeper zone the limited number of nitrifying bacteria present at the premise of the USG and converts a limited portion of urea to $\mathrm{NO}_{3}^{-1}$ and takes more time to convert whole USG as compared to PU which may be utilized by the plant throughout the whole growing period. 


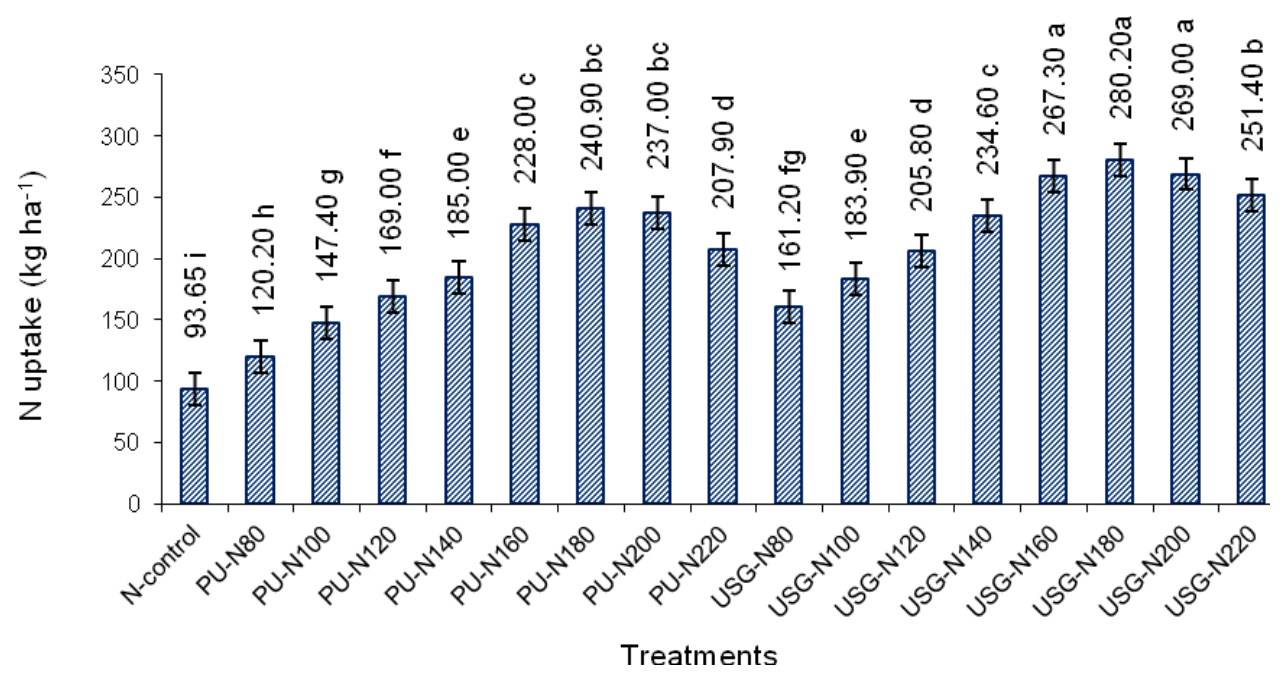

Figure 1. Effect of different levels of USG and PU on $\mathrm{N}$ uptake by the broccoli plant. Vertical bars showed standard error.

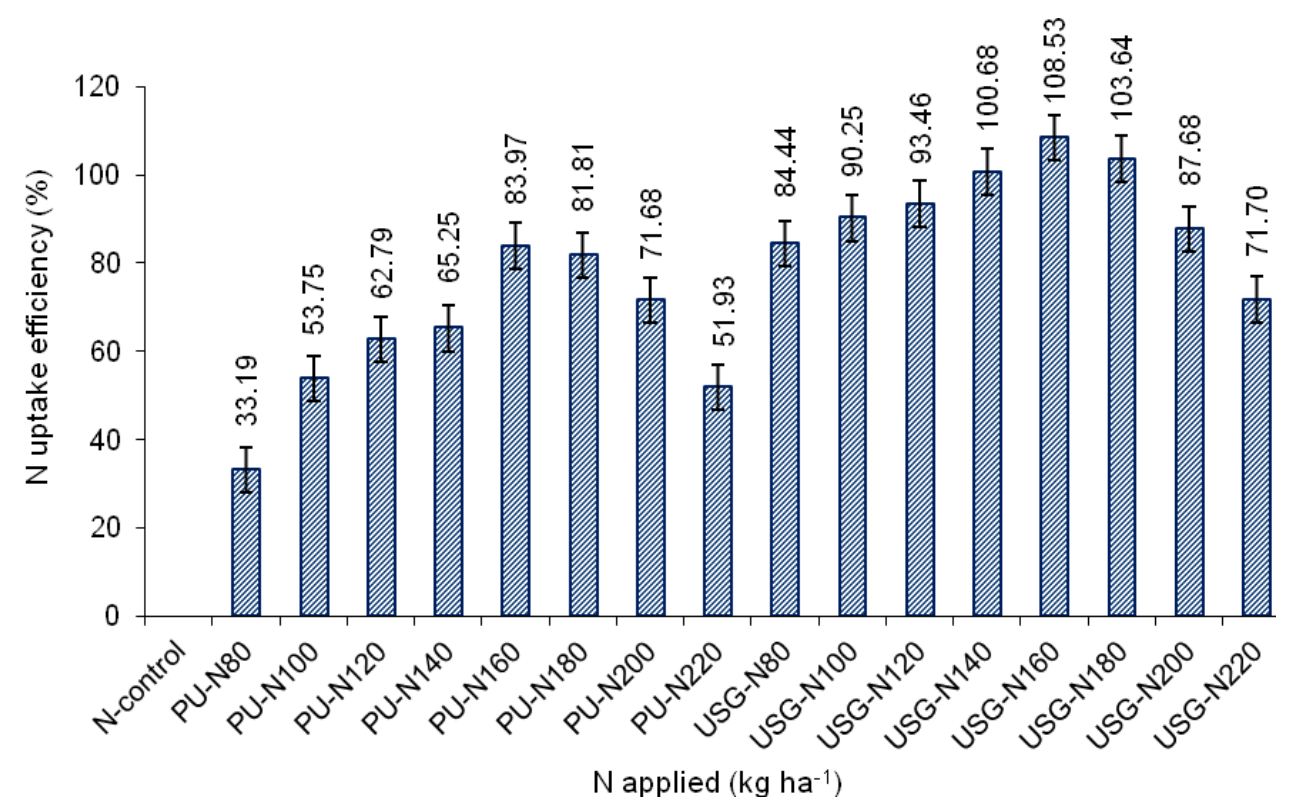

Figure 2. Effect of different levels of USG and PU on N uptake efficiency of broccoli plant. Vertical bars showed standard error. 
Mukherjee (1986) explained this phenomenon as the USG with deep placement provided a zone of concentrated urea solution where the denitrifying bacteria cannot enter and therefore $\mathrm{N}$ is left at the root zone for uptake by the plants. This result is in agreement with Khalil et al. (2011) who reported that deeper placements of USGs (5.0$7.5 \mathrm{~cm})$ resulted in greater fertilizer-N recovery in the crop (70.5-78.0\%) compared to the use of prills $(56.6 \%)$. They strongly suggested that the proper application of USGs can increase yields and fertilizer-N utilization of wheat and simultaneously decrease $\mathrm{N}$ losses compared to equivalent use of prills, and therefore presents important agronomic advantages.

\subsubsection{Nitrogen uptake efficiency}

From Fig. 2, it was found that the $\mathrm{N}$ uptake efficiency was increased (up to $83.969 \%$ and $108.531 \%$ ) with increasing levels of $\mathrm{N}$ up to the treatment PU-N $\mathrm{N}_{160}$ and USG-N $\mathrm{N}_{160}$ and then it was decreased. Rashid et al. (1996) reported that USG $\mathrm{N}$ was more efficiently used than that of PU and they stated that deep placement of USG is an effective means of increasing $\mathrm{N}$ use efficiency of rice as compared to the traditional split application of PU. Zebarth et al. (1995) also stated that apparent fertilizer- $\mathrm{N}$ recovery in the aboveground portion of the plant decreased linearly from between 46 and $93 \%$ at a $\mathrm{N}$ rate of $125 \mathrm{~kg} \mathrm{ha}^{-1} \mathrm{~N}$ to between 20 and $4 \%$ at an $\mathrm{N}$ rate of $625 \mathrm{~kg} \mathrm{ha}^{-1}$. Moreover, apparent fertilizer-N recovery in the harvested portion of the plant decreased linearly from between 14 and $25 \%$ at an $\mathrm{N}$ rate of $125 \mathrm{~kg} \mathrm{ha}^{-1}$ to between 8 and $14 \%$ at an $\mathrm{N}$ rate of $625 \mathrm{~kg} \mathrm{ha}^{-1}$. Most studies have shown that the $\mathrm{N}$ use efficiency (NUE) of broccoli decreased with increasing amount of $\mathrm{N}$ application (Zebarth et al., 1995; Tremblay and Beaudet, 2006 and Khalil et al. 2011).

\subsubsection{Phosphorus uptake by the crop}

Phosphorus uptake $(24.678 \mathrm{~kg}$ and $28.255 \mathrm{~kg} \mathrm{P}$ $\mathrm{ha}^{-1}$ ) was increased significantly with increasing levels of urea $\mathrm{N}$ up to the treatment PU-N $\mathrm{N}_{180}$ and USG-N $\mathrm{N}_{180}$ and then decreased with a curviliniar fashion (Fig. 3). Overall, higher $\mathrm{P}$ uptake was found from USG treated plots as compare to that of PU. This is due to continuous supply, higher $\mathrm{P}$ use efficiency and greater fertilizer-P recovery in case of USG than that of PU. Fatemeh and Ahmad (2012) reported that the P, K, and concentrations in broccoli head were significantly increased by $\mathrm{N}$ treatments and reached maximum at $300 \mathrm{~kg} \mathrm{~N}$ ha- 1 dose which is in agreement with this study. As the $\mathrm{N}$ conversion to nitrate in soil and nitrate absorption by roots makes negative charge in root cells and the plants for equilibrium charge in cells proceed to the cation absorption. Therefore, absorption of $\mathrm{K}$ and $\mathrm{P}$ is increased by the plant (Uygur and Rimmer, 2000 and Moniruzzaman et al., 2007). The results were similar to Yoldas et al. (2008) in broccoli and Abdelrazzag (2002) and Magnusson (2002) on several vegetable crops. Edson et al. (2012) also reported that $\mathrm{P}-\mathrm{TSP}$ recovery by corn increased with $\mathrm{N}$ increasing rates.

\subsubsection{K uptake by the crop}

Potassium uptake (214.4 kg and $227.40 \mathrm{~kg} \mathrm{~K} \mathrm{ha-}$ $\left.{ }^{1}\right)$ was increased significantly with increasing levels of $\mathrm{N}$ up to $180 \mathrm{~kg}$ both for PU and USG and then it decreased in a curvilinear fashion (Fig. 4). The higher uptake was found from USG treated plots than that of PU. This is might be due to the synergistic effect of $\mathrm{K}$ with $\mathrm{N}$ which might help continuous supply, higher $\mathrm{K}$ uptake efficiency and greater fertilizer-K recovery in case of USG than that of PU. Yoldas et al. (2008) reported that application of $\mathrm{N}$ increased $\mathrm{N}, \mathrm{P}, \mathrm{K}$ and Fe concentrations in broccoli head. They revealed the highest concentrations of $\mathrm{N}$ and $\mathrm{K}$ in broccoli head under the application of $\mathrm{N}$ at $450 \mathrm{~kg} \mathrm{ha}^{-1}$. Abdelrazzag (2002) and Magnusson (2002) obtained similar results on several vegetable crops. The similar reason as stated earlier in $\mathrm{P}$ uptake is applicable for absorption of more $\mathrm{K}$ by the plant according to Uygur and Rimmer (2000) and Moniruzzaman et al. (2007). 


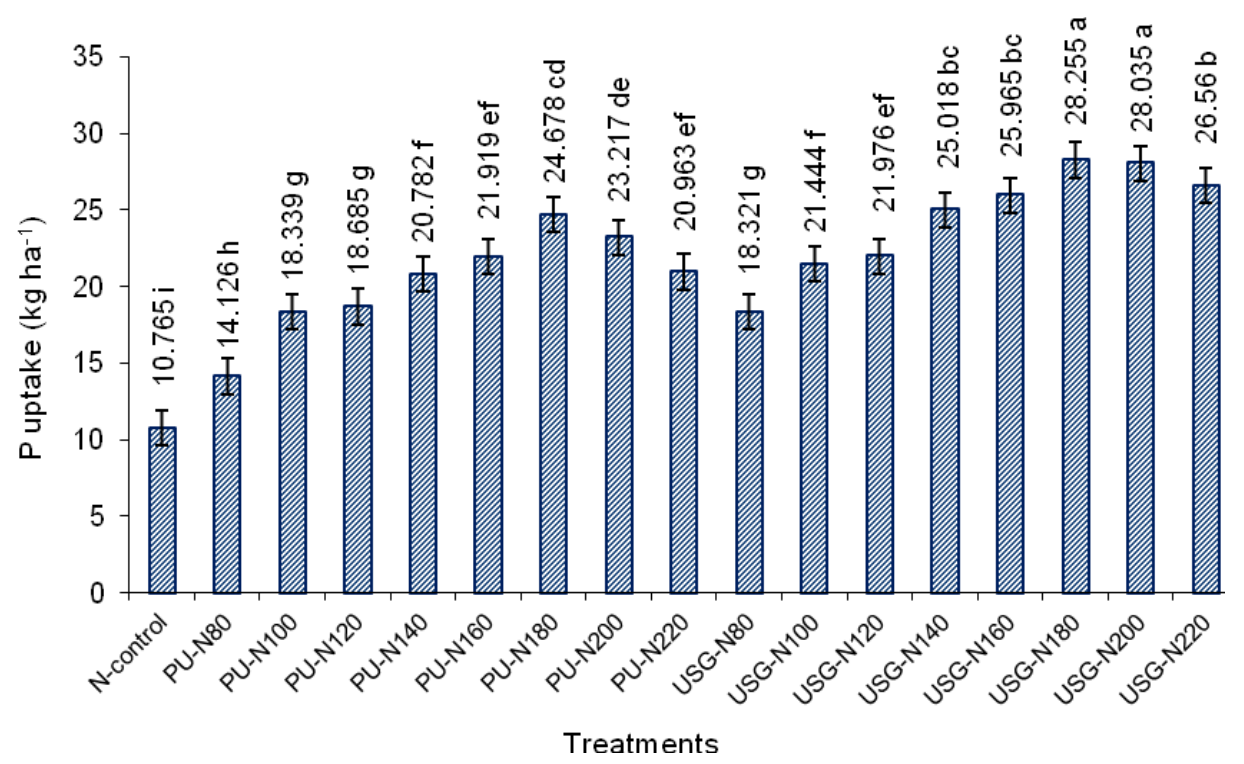

Figure 3. Effect of different levels of USG and PU on the P uptake of broccoli. Vertical bars showed standard error.

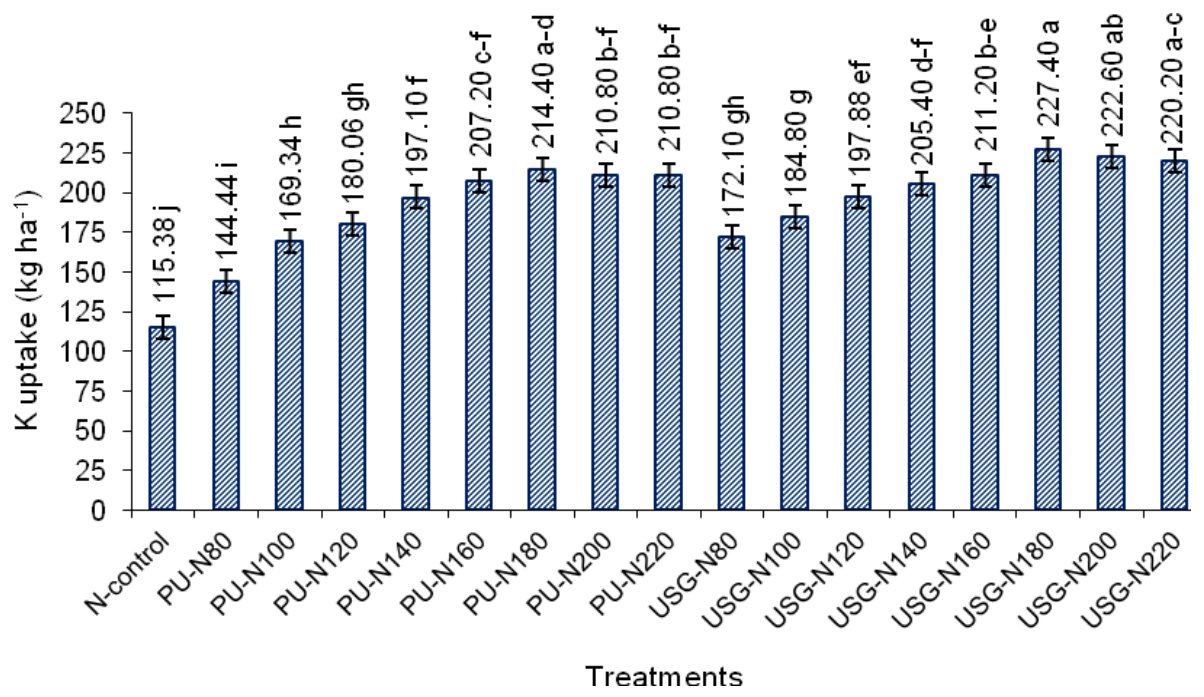

Figure 4. Effect of different levels of USG and PU on the K uptake of broccoli. Vertical bars showed standard error. 


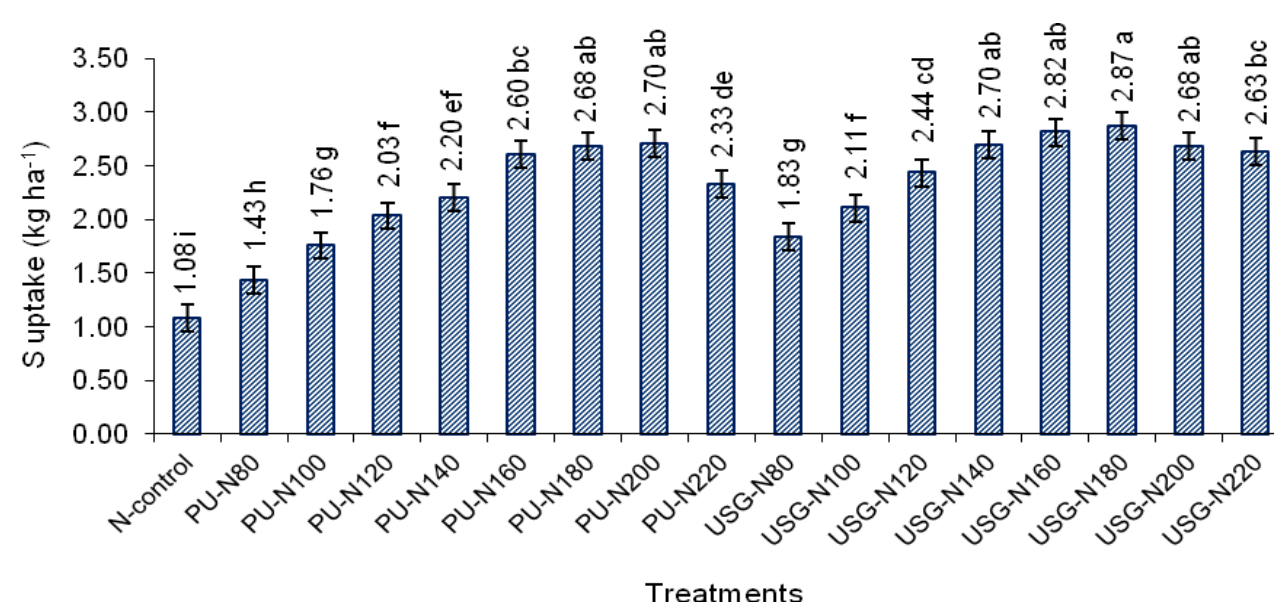

Figure 5. Effect of different levels of USG and PU on the S uptake of broccoli. Vertical bars showed standard error.

\subsubsection{S uptake by the crop}

Sulphur uptake was increased significantly with increasing levels of $\mathrm{N}$ up to $180 \mathrm{~kg}$ both for PU (2.684 kg S ha ${ }^{-1}$ ) and USG (2.871 kg S ha ${ }^{-1}$ ) and then it decreased in a curvilinear fashion (Fig. 5). The higher uptake was found from USG treated plots as compared to that of PU. This is due to continuous supply of $\mathrm{N}$, which induces higher growth which in turns the plant taken up more $\mathrm{S}$ as well as higher $\mathrm{S}$ use efficiency and greater fertilizer-S recovery in case of USG than that of PU. Abd el-All and EL-Shabrawy (2013) reported that increasing levels of nitrogen application significantly increased total N, P and $\mathrm{S}$ contents in broccoli and the highest values were obtained by fertilization broccoli plant with $80 \mathrm{~kg} \mathrm{~N} / \mathrm{fed}$. Aires et al. (2007) found that N fertilization significantly influenced the uptake of $\mathrm{N}, \mathrm{S}, \mathrm{K}, \mathrm{Ca}, \mathrm{Mg}, \mathrm{Na}, \mathrm{Cl}$ and silicon of broccoli sprouts which is in agreement with the present study.

\subsection{Effects on post-harvest soil nutrient status 3.3.1. Total soil $N$ content}

Total $\mathrm{N}$ content of post-harvest soil showed a significant variation among the treatments (Table $3)$. The highest total $\mathrm{N}(0.107 \%)$ was obtained from USG-N $\mathrm{N}_{220}$ followed by USG-N $\mathrm{N}_{200}$ which was statistically identical with USG-N $\mathrm{N}_{100}$, USG$\mathrm{N}_{120}$, USG- $\mathrm{N}_{140}$, USG-N $\mathrm{N}_{160}$, USG-N $\mathrm{N}_{180}, \mathrm{PU} \mathrm{N}_{180}$ and the control. The lowest $\mathrm{N}$ content was found from PU-N 200 and PU-N 220 . These lower soil N contents might be due to the consequence of higher uptake rate of $\mathrm{N}$ by the crop as the supply was not adequate according to demand. However, deep placement of USG limits the volatilization loss, which results higher residual soil $\mathrm{N}$ content where $\mathrm{N}$ supply was also sufficient for crop requirement. Averaarts and de Willigen (1999) reported that the amount of mineral $\mathrm{N}$ in the soil at harvest generally increased with increasing amounts of $\mathrm{N}$ applied.

\subsubsection{Available soil $P$ content}

Post harvest soil $\mathrm{P}$ was significantly influenced by different treatments (Table 3) and the highest available soil $\mathrm{P}\left(17.38 \mu \mathrm{g} \mathrm{g}^{-1}\right)$ was recorded from control followed by $80 \mathrm{~kg} \mathrm{~N}$ for both PU and USG (17.25 $\mu \mathrm{g} \mathrm{g} \mathrm{g}^{-1}$ ) which was statistically identical with PU-N $\mathrm{N}_{100}$ and USG-N $\mathrm{N}_{100}$. It was observed that residual soil $\mathrm{P}$ content was decreased with increasing rate of $\mathrm{N}$ application and the minimum $\mathrm{P}$ content $\left(13.89 \mu \mathrm{g} \mathrm{g}^{-1}\right)$ was found from PU-N 200 followed by USG-N ${ }_{180}$

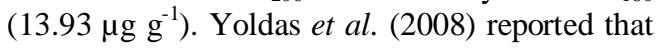
application of nitrogen increased $\mathrm{N}, \mathrm{P}, \mathrm{K}$ and Fe 
concentrations in broccoli head. Utilization of fertilizer $\mathrm{P}$ is generally enhanced by the application of $\mathrm{N}$ (William, 1958). Therefore, reduction of $\mathrm{P}$ in soil in higher $\mathrm{N}$ levels might be due to the consequence of higher $\mathrm{P}$ uptake with higher crop growth induced by higher rate of $\mathrm{N}$ application. Aydin et al. (2008) reported that increasing levels of $\mathrm{N}$ negatively correlated with plant $\mathrm{P}$ and positively correlated with $\mathrm{Ca}, \mathrm{Fe}$, and $\mathrm{Zn}$ which is somehow differ from our result. In support in my results root architecture plays an important role in maximizing $\mathrm{P}$ acquisition because root systems with higher surface area are able to explore a given volume of soil more effectively (Lynch, 1995). Root architecture that distributes more roots to the place where $\mathrm{P}$ resources are located plays an important role in efficiently exploiting these $\mathrm{P}$ resources (Jianbo et al., 2011). Localized application of phosphates plus ammonium significantly enhances $\mathrm{P}$ uptake and crop growth through stimulating root proliferation and rhizosphere acidification in a calcareous soil (Jing et al., 2010). The chemical and biological processes in the rhizosphere not only determine mobilization and acquisition of soil nutrients as well as microbial dynamics, but also control nutrient-use efficiency of crops, and thus profoundly influence crop productivity (Richardson et al., 2009 and Zhang et al., 2010). Soluble $P$ in the rhizosphere soil solution should be replaced 20 to 50 times per day by $\mathrm{P}$ delivery from bulk soil to the rhizosphere to meet plant demand (Marschner, 1995). Therefore, $\mathrm{P}$ dynamics in the rhizosphere are mainly controlled by plant root growth and function, and also highly related to physical and chemical properties of soil (Neumann and Römheld, 2002).

Table 3. Effect of different levels of USG and PU on the post harvest soil nutrient status of broccoli plot

\begin{tabular}{|c|c|c|c|c|c|}
\hline Treatment & $\begin{array}{l}\text { Soil total } \\
\mathrm{N}(\%)\end{array}$ & $\begin{array}{l}\text { Available } \\
\text { soil } \mathrm{P}\left(\mu \mathrm{g} \mathrm{g}^{-1}\right)\end{array}$ & $\begin{array}{l}\text { Exchangeable } \\
\text { soil K (me/100g) }\end{array}$ & $\begin{array}{l}\text { Soil available } \\
\mathrm{S}\left(\mu \mathrm{g} \mathrm{g}^{-1}\right)\end{array}$ & $\begin{array}{l}\text { Soil available } \\
\mathrm{B}\left(\mu \mathrm{g} \mathrm{g}^{-1}\right)\end{array}$ \\
\hline $\mathrm{N}$-control & 0.092 a-c & $17.38 \mathrm{a}$ & $0.379 \mathrm{a}$ & $19.85 \quad \mathrm{a}$ & $0.332 \mathrm{a}$ \\
\hline PU-N 80 & $0.086 \mathrm{bc}$ & $17.25 \mathrm{a}$ & $0.352 \mathrm{bc}$ & $17.02 \mathrm{~b}$ & $0.311 \mathrm{a}$ \\
\hline PU-N 100 & $0.101 \mathrm{ab}$ & $16.91 \mathrm{ab}$ & $0.358 \mathrm{bc}$ & $16.07 \mathrm{c}$ & $0.311 \mathrm{a}$ \\
\hline PU-N 120 & $0.103 \mathrm{ab}$ & $16.12 \mathrm{c}$ & $0.347 \mathrm{c}$ & $15.29 \mathrm{~d}$ & $0.291 \mathrm{ab}$ \\
\hline PU-N 140 & $0.092 \mathrm{a}-\mathrm{c}$ & $16.00 \mathrm{c}$ & $0.347 \mathrm{c}$ & $14.34 \mathrm{e}$ & $0.291 \mathrm{ab}$ \\
\hline PU-N 160 & $0.098 \mathrm{a}-\mathrm{c}$ & $14.98 \mathrm{~d}$ & $0.326 \mathrm{~d}$ & $14.34 \mathrm{e}$ & $0.252 \mathrm{bc}$ \\
\hline PU-N 180 & $0.098 \mathrm{a}-\mathrm{c}$ & 14.19 ef & $0.326 \mathrm{~d}$ & $12.29 \mathrm{f}$ & 0.249 b-d \\
\hline PU-N 200 & $0.081 \mathrm{c}$ & $13.89 \mathrm{f}$ & $0.316 \mathrm{~d}$ & $10.40 \mathrm{~h}$ & $0.249 \mathrm{~b}-\mathrm{d}$ \\
\hline PU-N 220 & $0.081 \mathrm{c}$ & $14.41 \mathrm{~d}-\mathrm{f}$ & $0.358 \mathrm{bc}$ & $12.29 \mathrm{f}$ & $0.226 \mathrm{~cd}$ \\
\hline USG-N ${ }_{80}$ & $0.084 \mathrm{bc}$ & $17.25 \mathrm{a}$ & $0.384 \mathrm{a}$ & $14.18 \mathrm{e}$ & $0.260 \mathrm{bc}$ \\
\hline USG-N $_{100}$ & 0.089 a-c & $16.97 \mathrm{a}$ & $0.368 \mathrm{ab}$ & $11.34 \mathrm{~g}$ & $0.260 \mathrm{bc}$ \\
\hline USG-N $_{120}$ & 0.089 a-c & $16.29 \mathrm{bc}$ & $0.347 \mathrm{c}$ & $10.40 \mathrm{~h}$ & $0.256 \mathrm{bc}$ \\
\hline USG-N ${ }_{140}$ & $0.092 \mathrm{a}-\mathrm{c}$ & $15.69 \mathrm{c}$ & $0.347 \mathrm{c}$ & 9.45 & 0.249 b-d \\
\hline USG-N $_{160}$ & $0.092 \mathrm{a}-\mathrm{c}$ & $14.63 \mathrm{de}$ & $0.326 \mathrm{~d}$ & 8.77 & 0.249 b-d \\
\hline USG-N $_{180}$ & $0.104 \mathrm{ab}$ & 13.93 ef & $0.326 \mathrm{~d}$ & 8.35 & 0.249 b-d \\
\hline USG-N 200 & 0.106 a & 13.96 ef & $0.358 \mathrm{bc}$ & 8.77 & $0.209 \mathrm{~cd}$ \\
\hline USG-N $_{220}$ & $0.107 \mathrm{a}$ & $14.64 \mathrm{de}$ & $0.358 \mathrm{bc}$ & 8.77 & $0.197 \mathrm{~d}$ \\
\hline $\mathrm{CV}(\%)$ & 5.01 & 1.42 & 2.65 & 2.12 & 8.64 \\
\hline $\mathrm{SE}( \pm 0.05)$ & 0.00577 & 0.22033 & 0.00577 & 0.20016 & 0.01534 \\
\hline
\end{tabular}

Means followed by uncommon letters are statistically different from each other at $5 \%$ level of probability by DMRT 


\subsubsection{Exchangeable soil $K$ content}

The different forms and levels of $\mathrm{N}$ fertilizer significantly influenced the exchangeable soil K of post harvest soil (Table 3). The highest exchangeable soil K $(0.384 \mathrm{me} / 100 \mathrm{~g}$ soil $)$ was found from the treatment USG-N $\mathrm{N}_{80}$ which was statistically identical with control $(0.379$ $\mathrm{me} / 100 \mathrm{~g}$ soil) and USG-N $\mathrm{N}_{100}$ treatment. The lowest $\mathrm{K}$ content $(0.316$ (me/100g soil) was recorded from the treatment $\mathrm{PU}-\mathrm{N}_{200}$ that might be due to higher $\mathrm{K}$ uptake with higher crop growth as induced by higher rate of $\mathrm{N}$ application. Crops respond to higher $\mathrm{K}$ levels when $\mathrm{N}$ is sufficient, and greater yield response to $\mathrm{N}$ fertilizer occurs when $\mathrm{K}$ is sufficient (http://www.ipni.net/publication/bettercrops,

1998). So, at higher N levels crop growth will be higher and $\mathrm{K}$ uptake also higher as result lower soil $\mathrm{K}$ content was reflected.

\subsubsection{Soil available $S$ content}

In case of post harvest soil a significant variation was observed among the treatments (Table 3). Accordingly, the highest $\mathrm{S}$ content $\left(19.85 \mu \mathrm{g} \mathrm{g}^{-1}\right)$ was recorded from control, which was statistically higher than all other treatment combinations. A decreasing trend was observed in $\mathrm{S}$ content with the increasing rates of $\mathrm{N}$ application and lower $S$ content was found in USG treated plots as compared to that of PU. It might be due to higher S uptake by the plant with higher crop growth favored by sufficient supply of $\mathrm{N}$. The minimum $\mathrm{S}$ content $\left(8.35 \mu \mathrm{g} \mathrm{g}^{-1}\right)$ was estimated from the treatment USG-N $\mathrm{N}_{180}$, which was statistically similar to USG-N $\mathrm{N}_{160}$, USG-N $\mathrm{N}_{200}$ and USG-N $\mathrm{N}_{220}$ treatments. This indicated that higher $\mathrm{N}$ rate induced higher crop growth and consequently higher $\mathrm{S}$ uptake which reduced the soil $\mathrm{S}$ content as well.

\subsubsection{Soil B content}

The post harvest soil B content showed a significant difference among the treatments. (Table 3). It was observed that post harvest soil $\mathrm{B}$ content was decreased with increasing rate of $\mathrm{N}$. The maximum soil B content $\left(0.332 \mu \mathrm{g} \mathrm{g}^{-1}\right)$ was found in control, which was statically identical with PU-N $80, P U-\mathrm{N}_{100}, \mathrm{PU}-\mathrm{N}_{120}$, and
PU-N ${ }_{140}$ and the lowest $\left(0.197 \mu \mathrm{g} \mathrm{g}^{-1}\right)$ was found from USG- $\mathrm{N}_{220}$ treated plot. As $\mathrm{B}$ is an intermediate mobile element and it was applied in the soil it's uptake was also restricted. Its uptake is defends on the crop growth and higher uptake will be for higher crop growth accelerated by the higher rate of $\mathrm{N}$. Consequently, B content was higher in the soil where lower doses of $\mathrm{N}$ used.

\section{Conclusions}

According to the experimental outcome generated from the above mentioned experiment it was concluded that compactness coefficient, beta-carotene, Chlorophyll-a and Chlorophyll-b content were significantly increased with increasing levels of nitrogenous fertilizer, and USG performed better than that of PU for all the quality attributes but ascorbic acid content was slightly decreased with increasing rate of USG and PU. The USG showed better compactness coefficient (18.24 to 18.61), $\beta$-carotene (0.401 mg $\left.100 \mathrm{~g}^{-1} \mathrm{FW}\right)$ and chlorophyll contents

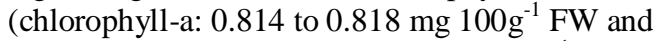

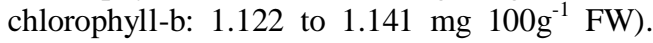
Plant nutrient status was also higher in higher doses of $\mathrm{N}$ as well as USG and it was higher than PU but $\mathrm{N}$ uptake efficiency was decreased with increasing rates of $\mathrm{N}$ fertilizer. The higher nutrient (NPKS) uptake and $\mathrm{N}$ uptake efficiency (maximum 108.53\%) was found in USG treated plots over PU. Post harvest soil nutrient status was increased with increasing rates of $\mathrm{N}$ as well as USG which was also higher than PU. From this study it was found that the treatment USG$\mathrm{N}_{160}$ followed by USG-N $\mathrm{N}_{140}$ and USG-N $\mathrm{N}_{180}$ and the treatment PU-N $\mathrm{N}_{180}$ with other recommended doses of fertilizer performed better those could be suggested as a good treatment combinations for broccoli production in terms of yield, quality and nutrient status in Shallow Red-Brown Terrace Soil under Madhupur Tract (AEZ-28).

\section{References}

Abd el-All, H. M. and EL- Shabrawy, R.A. 2013. Effect of some phosphorus sources, nitrogen and sulphur levels on yield, quality, sulforaphane and Vit. C content in 
broccoli. Research Journal of Agriculture and Biological Sciences, 9(6): 351-365, 2013.

Abdelrazzag, A. 2002. Effect of chicken manure, sheep manure and inorganic fertilizers on yield and nutrient uptake by onion. Pakistan Journal of Biological Science, 5: 266-268.

Aires, A., E. Rosa, C. Rosa, S. Haneklaus and E. Schnug, 2007. Influence of nitrogen and sulphur on the mineral composition of broccoli sprouts. Journal of plant Nutrition, 30(7): 1035-1046.

Anton Uher, Miroslav Šlosár, Tomáš Lošák, Jaroslav Hlušek, 2014. The effect of differentiated nutrition on the content of antioxidants in broccoli. Acta Universitatis Agriculturae et Silviculturae Mendelianae Brunensis, 62 (3): 561-564.

Arisha, H. M. and Bradisi, A. 1999. Effect of mineral fertilizers and organic fertilizers on growth, yield and quality of potato under sandy soil conditions. Zagazig Journal of Agriculture and Research, 26: 391-405.

Aydin Gunes, Mehmet Alpaslan and Ali Inal, 2008. Critical nutrient concentrations and antagonistic and synergistic relationships among the nutrients of NFT-grown young tomato plants. Journal of plant nutrition, 21(10): 2035-2047.

Bakker, C. J., Swanton, C. J. and McKeown, A. W. 2009. Broccoli growth in response to increasing rates of pre-plant nitrogen. I Yield and quality. Canadian Journal of Plant Science. 89: 527-537.

Black, C. A. 1965. Methods of soil analysis, Part-I and II. American Society of Agronomy. Inc. Pub. Madison, Wisconsin, USA: 30-48.

Chao-Jiong $\mathrm{Xu}$, Rong-Fang Guo, Hui-Zhuan Yan, Jing Yuan, Bo Sun, Gao-Feng Yuan and Qiao-Mei Wang, 2010. Effect of nitrogen fertilization on ascorbic acid, glucoraphanin content and quinine reductase activity in broccoli floret and stem. Journal of Food, Agriculture and Environment, 8(1): 179-184.

Craswell, E. T. and Godwin, D. C. 1984. The efficiency of nitrogen fertilizers applied to cereals in different climates. Pp. 1-55. In: Tinker, P. B. and äuchli, A. (eds.): Advances in Plant Nutrition, vol. I. Praeger Publishers, New York.

Edson Cabral da Silva, Takashi Muraoka, Vinícius Ide Franzini, Felipe Carlos Alvarez Villanueva, Salatiér Buzetti and Dolorice Moreti, 2012. Phosphorus utilization by corn as affected by green manure, nitrogen and phosphorus fertilizers. Pesquisa agropecuaria brasileira, 47 (8):1150-1157.

Everaarts A. P., de Willigen P. 1999. The effect of the rate and method of nitrogen application on nitrogen uptake and utilization by broccoli (Brassica oleracea var. italica). Netherlands Journal of Agricultural Science, 47:201-214.

Fatemeh Rakhsh and Ahmad Golchin, 2012. Effects of nitrogen and boron on growth, yield and nutrient concentrations in broccoli. International Journal of Agriculture: Research and Review, 2(5): 646-651.

Greenwood, D. J. and Draycott, A. 1988. Recovery of fertilizer-N by diverse vegetable crops: Process and models. In: Nitrogen efficiency in agricultural soils (Jenkinson D. S. and Smith K. A., Eds) Elsevier, London and New York, 46-61 pp.

Hochmuth, G. J., Brecht, J. K. and Basset, M. J. 1999. Nitrogen fertilization to maximize carrot yield and quality on a sandy soil. Horticultural Science, 34(4): 641-645.

http://www.ipni.net/publication/bettercrops, 1998. Potassium interactions with other nutrients, Better Crops. 82 (3): 12-13. 
Hunter, A. H. 1980. 'Soil fertility Analytical Service in Bangladesh' consultancy report, BJRI project phase II, BARC, Dhaka, Bangladesh.

Jackson, M. L. 1962. Soil chemical analysis. Prentice Hall Inc. Engle Wood Cliffs, N. J., USA, 55-56 pp.

Jackson, M. L. 1973. Soil Chemical Analysis. Prentice Hall of India Pvt. Ltd. New Delhi, India.

Jianbo Shen, Lixing Yuan, Junling Zhang, Haigang Li, Zhaohai Bai, Xinping Chen, Weifeng Zhang, and Fusuo Zhang. 2011. Phosphorus Dynamics: From Soil to Plant. Plant Physiology, 156(3): 9971005.

Jing, J. Y., Rui, Y. K., Zhang, F. S., Rengel, Z., Shen, J. B. 2010. Localized application of phosphorus and ammonium improves growth of maize seedlings by stimulating root proliferation and rhizosphere acidification. Field Crops Research, 119: 355-364.

Karitonas, R. 2001. Effect of nitrogen supply on yield and quality of broccoli. Plant nutrition food security and sustainability of agro-ecosystems through basic and applied research. Fourteenth International Plant Nutrition Colloquium, Hannover, Germany, 298-299 pp.

Kays, W. R. 1914. Growing broccoli, cauliflower, and cabbage. Oklahoma Cooperative Extension Service. Oklahoma State University, Division of Agricultural Sciences and Natural Resources, Oklahoma State University.

Khalil, M. I. Schmidhalter, U. Gutser, R. and Heuwinkel, H. 2011. Comparative efficacy of urea fertilization via supergranules versus prills on nitrogen distribution, yield response and nitrogen use efficiency of spring wheat. Journal of Plant Nutrition, 34(6): 779-797.

Khalil, M. I., Schmidhalter, U. and Gutser. R. 2006. $\mathrm{N}_{2} \mathrm{O}, \mathrm{NH}_{3}$ and NOx emissions as a function of urea granule size and soil type under aerobic conditions. Water, Air and Soil Pollution, 175:127-148.

Lisiewska, Z. and Kmiecik, W. 1996. Effects of level of nitrogen fertilizer, processing conditions and period of storage of frozen broccoli and cauliflower on vitamin $\mathrm{C}$ retention. Food Chemistry, 57(2): 267270.

Ljiljana Boskovic-Rakocevic, Rados Pavlovic , Jasmina Zdravkovic, Milan Zdravkovic, Nenad Pavlovic and Milena Djuric, 2012. Effect of nitrogen fertilization on carrot quality. African Journal of Agricultural Research, 7(18): 2884-2900.

Lynch, J. P. 1995. Root architecture and plant productivity. Plant Physiology, 109: $7-$ 13.

Magnusson, M. 2002. Mineral fertilizers and green mulch in Chinese cabbage (Brassica Pekinensis Rupr): effect on nutrient uptake, yield and internal tipburn. Soil and Plant Science, 52: 25-35

Marschner, H. 1995. Mineral Nutrition of Higher Plants, Ed 2 Academic Press, London, 889 p.

Masayasu Nagata and Ichiji Yamashita, 1992. Simple method for simultaneous determination of chlorophyll and carotinoids in tomato fruit. Journal of Japan Society of Food Science and Technology (Nippon Shokuhin Kogio Gakkaishi), 39(10): 925-928.

Moniruzzaman, M. Rahman, S. M. L. Kibria, M. Grahman, M. A. and Hossain, M. M. 2007. Effect of boron and nitrogen on yield and hollow stem of broccoli. Journal of Soil and Nature, 1(3):24-29.

Murcia, M. A. López-Ayerra, B. MartínezTomé, M. and García-Carmona, F. 2000. Effect of industrial processing on chlorophyll content of broccoli. Journal of the Science of Food and Agriculture, 80: 1447-1451. 
Neeteson, J. J. and Carton, O. T. 2001. The environmental impact of nitrogen in field vegetable production. Acta Horticulture. 563: 21-28.

Neumann, G., Römheld, V. 2002. Root-induced changes in the availability of nutrients in the rhizosphere. Waisel, Y, Eshel, A, Kafkafi, U, editors., Plant Roots. The Hidden Half, Ed 3 Marcel Dekker, Inc., New York, 617-649 pp.

Olsen, S. R, Cole, C.V. Watanable, F.S. and Dean, L.A. 1954. Estimation of available phosphorus in soils by extraction with sodium bicarbonate. U.S., Dept. Agric. Circular: 207-215 pp.

Ouda, B. A. and Mahadeen, A.Y. 2008. Effect of fertilizers on growth, yield, yield components, quality and certain nutrient contents in broccoli (Brassica oleracea). International Journal of Agriculture and Biology, 10(6): 627-632.

Page, A. L. Miller, R. H. and Keeney, D. R. 1982. Methods of soil analysis. Part 2, $2^{\text {nd }}$ ed. American Society of Agronomy, Inc. Madi, Wis, USA.

Piper, G. S. 1950. Soil and Plant Analysis. Adelaide University Press, Australia.

Rashid, M. A. Billah, K. A. Mazid, M. A. and Jameel, F. 1996. Nirogen use efficiency of urea super granules and prilled urea in irrigated rice cultivation. Bangladesh Rice Journal, 7:41-44.

Renata Wojciechowska, Stanisław RoŜek and Agata Rydz, 2005. Broccoli yield and its quality in spring growing cycle as dependent on nitrogen fertilization. Folia Horticulturae Annals, 17 (2):141-152.

Richardson, A. E., Barea, J. M., McNeill, A. M., Prigent-Combaret, C.2009. Acquisition of phosphorus and nitrogen in the rhizosphere and plant growth promotion by microorganism. Plant and Soil, 321: 305-339.

Roni, M. S., Zakaria, M., Hossain, M. M. and Siddiqui, M. N. 2014. Effect of plant spacing and nitrogen levels on nutritional quality of broccoli (Brassica oleracea L.). Bangladesh Journal of Agricultural research, 39(3):491-504.

Tremblay, N. and Beaudet, P. 2006. Soil Nmin content and $\mathrm{P}_{2} \mathrm{O}_{5}$ export from vegetable crops in Quebec (Canada). Acta Horticulturae, 700: 185-189.

Uygur, V. and Rimmer, D. L. 2000. Reactions of zinc with iron coated calcite surfaces at alkaline pH. Europian Journal of Soil Science, 51:511-515.

William Frederick Bennet, 1958. Effect of nitrogen on phosphorus absorption by corn. Retrospective Theses and Dissertations, Iowa State College, Iowa State College. 175p.

Yoldas, F. Ceylan, S. Yagmur, B. and Mordogan, N. 2008. Effect of nitrogen fertilizer on yield quality and nutrient content in broccoli. Journal of Plant Nutrition, 31(7): 1333-43.

Zebarth, B. J. Bowen, P. A. and Toivonen, P. M. A. 1995. Influence of nitrogen fertilization on broccoli yield, nitrogen accumulation and apparent fertilizer-nitrogen recovery. Canadian Journal of Plant Science, 75(3): 717-725.

Zhang, F., Shen, J., Zhang J., Zuo, Y., Li, L., Chen, X. 2010. Rhizosphere processes and management for improving nutrient use efficiency and crop productivity: implications for China. Advances in Agronomy, 107: 1-32. 